\title{
Perancangan dan Implementasi Alat Pengukur Tingkat Polusi Udara Karbon Monoksida dan Debu Berbasis Website Menggunakan Raspberry Pi
}

\author{
Riza Samsinar ${ }^{1}$, Ichsanul Fikri ${ }^{2}$, Fadliondi ${ }^{3}$ \\ 1,2,3 Teknik Elektro Universitas Muhammadiyah Jakarta \\ Jalan Cempaka Putih Tengah No.27, Jakarta \\ Email : ${ }^{1)}$ riza.samsinar@ftumj.ac.id , 2) 2014420024@ftumj.ac.id, ${ }^{3)}$ fadliondi@ftumj.ac.id
}

\begin{abstract}
ABSTRAK
Udara merupakan unsur terpenting dalam kehidupan manusia. polusi udarA muncul menjadi masalah yang serius di kota-kota besar, polutan yang ada di udara tersebut berbahaya bagi kesehatan manusia dan lingkungan. Untuk menyelesaikan masalah tersebut membuat perancangan dan implementasi alat pengukur tingkat polusi udara karbon monoksida dan debu berbasis website menggunakan raspberry pi. Bertujuan untuk mengetahui kadar polusi udara karbon monoksida dan debu. Supaya dapat dimonitoring melalui handphone dan laptop. Hasil dari alat perancangan dan implementasi alat pengukur tingkat polusi udara karbon monoksida dan debu. Untuk mengukur sebuah karbon monoksida dan mengukur debu pada polutan di luar ruangan seperti jalan raya yang dapat dimonitoring melalui handphone dan laptop. Dengan pengujian pada waktu berangkat kerja, waktu makan siang, dan waktu pulang kerja.
\end{abstract}

Kata kunci : karbon, monoksida, debu, website, raspberry pi

\begin{abstract}
Air is the most important element in human life. Air pollution appears to be a serious problem in big cities, the pollutants in the air are harmful to human health and the environment. To solve this problem, we designed and implemented a website-based measuring device for air pollution carbon monoxide and dust using raspberry pi. Aims to determine the level of air pollution, carbon monoxide and dust. So that it can be monitored via cellphones and laptops. The results of the design and implementation tools for measuring air pollution levels of carbon monoxide and dust. To measure a carbon monoxide and measure dust in outdoor pollutants such as roads that can be monitored via cellphones and laptops. By testing the time to go to work, time to eat lunch, and time to come home from work.
\end{abstract}

Keywords : carbon, monoxide, dust, websites, raspberry pi

\section{PENDAHULUAN}

Udara merupakan unsur terpenting dalam kehidupan manusia. polusi udara muncul menjadi masalah yang serius di kota-kota besar, polutan yang ada di udara tersebut berbahaya bagi kesehatan manusia dan lingkungan. Pada penelitian yang kami lakukan membuat suatu sistem pengukuran tingkat polusi udara menggunakan Raspberry pi berbasis website. Sensor berbiaya rendah menjadi semakin tersedia untuk mempelajari kualitas udara perkotaan [1]. Polusi udara perkotaan tetap menjadi risiko kesehatan yang penting bagi jutaan orang di negara berpenghasilan rendah [2]. Pemantauan indeks kualitas udara perkotaan secara harian adalah salah satu evaluasi kesehatan lingkungan [3]. Polusi merupakan masuknya makhluk hidup, zat, energi atau komponen lain dalam lingkungan yang menyebabkan berubahnya tatanan lingkungan oleh kegiatan manusia dan proses alam [4]. Sistem alat ukur aqms ini memonitoring tingkat polusi udara yang barada di lingkungan sekitar sehingga dapat memberikan informasi yang di perlukan bagi korban yang sensitif terhadap udara yang kurang sehat. Komponen elektronik terdiri dari sebuah, sensor gas Mq-7, sensor partikulat Sensor dust Sharp GP2Y1010AU0F, dll sebagai pelengkap komponen. System kendali ini menggunakan website sebagai monitoring hasil polusi udara karbon monoksida, dan debu untuk mengukur di luar ruangan. Tujuan penelitian ini membuat sebuah rancangan pada sistem AQMS (Air Quality Management System) untuk monitoring kualitas udara dan debu untuk mengetahui tingkat zat politan yang berada di lingkungan sekitar maupun di daerah industrial serta mendapatkan informasi atau laporan yang dapat di ambil untuk mengurangi korban - korban yang sensitif terhadap udara yang tidak sehat.

\section{METODOLOGI}

Monitoring kualitas udara karbon monoksida dan debu berbasis website menggunakan raspberry pi 


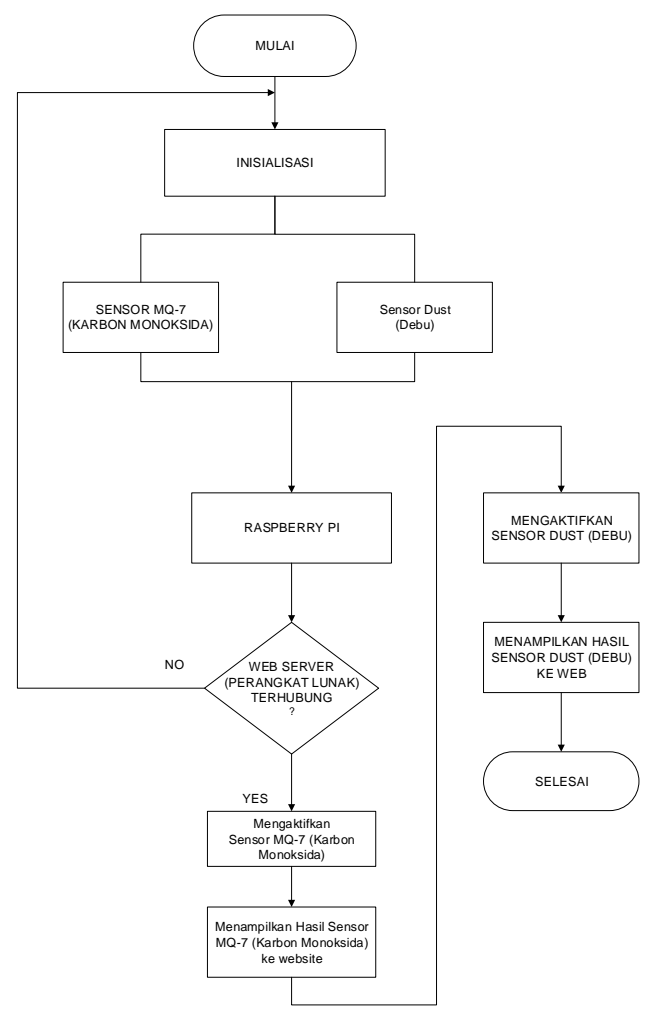

Gambar 1 Flowchart perancangan dan implementasi alat pengukur tingkat polusi udara karbon monoksida dan debu berbasis website menggunakan raspberry pi.

Perbedaan utama dan paling jelas antara Pi dan desktop adalah desktop hampir pasti memilikinya prosesor dari Intel atau AMD pada intinya [5]. Sistem operasi yang dapat digunakan pada Raspberry Pi antara lain Raspbian, Pidora, OpenElec, RaspBMC, RISC OS, Arch Linux ARM, dan lain-lain [6]. Raspberry Pi 3 Model B adalah Raspberry Pi generasi ketiga. Ini kuat Komputer papan tunggal berukuran kartu kredit dapat digunakan untuk banyak aplikasi [7].

Fungsi flowchart sistem ini sebagai sistem Kualitas Udara Karbon Monoksida dan Sensor Dust Sistem ini berkerja apabila semua inputan dari segi sensor MQ-7 dan sensor dust (debu), raspberry, semua sensor terhubung menggunakan raspberry. Sistem ini menggaktifkan Sensor MQ-7 dan Sensor Dust. Sensor MQ-7 dan sensor dust bekerja membaca nilai parameter karbon monoksida yang ada di pabrik maupun di jalan raya. kemudian mengirim data sensor karbon monoksida, dan sensor debu sharp gp2y1010au0f ke website.

Maksud dari Blok diagram Penggunaan dan Kualitas Udara Karbon Monoksida dan Debu. System ini untuk monitoring sebuah kualitas udara dengan parameter Karbon Monoksida dan debu melalui web. Sensor monoksida, dan sensor debu bekerja mendeteksi sebuah kualitas udara karbon monoksida, dan mendeteksi sebuah debu yang kemudian data tersebut dikirim melalui website supaya semua data yang terbaca oleh sensor dapat dimonitoring melalui handphone, dan laptop. Berikut adalah Blok Diagram Perencanaan dan perancangan perangkat keras.

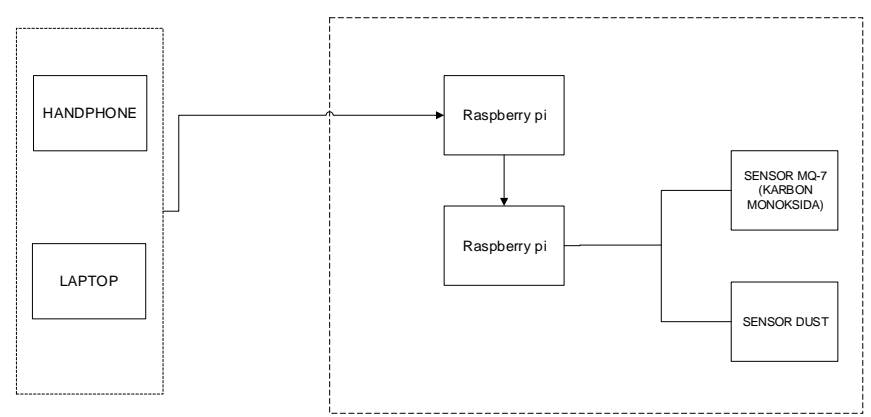

Gambar 2 Blok Diagram Monitoring Kualitas Udara Karbon Monoksida dan Debu Berbasis Website Menggunakan Raspberry Pi.

\section{Perancangan Perangkat keras}

Sensor MQ-7 (Karbon Monoksida) merupakan rangkaian yang terhubung dengan raspberry untuk membaca nilai parameter karbon monoksida yang terdapat pada jalan raya maupun pabrik. Raspberry pi tidak mempunyai pin analog maka digunakan ADC (Analog to digital converter). Kemudian sensor ini membaca parameter yang kemudian dikirim ke web untuk ditampilkan pada dashboard web tersebut. System web ini mempunyai status pada parameter Karbon Monoksida. System tersebut dapat di monitoring via handphone dan laptop supaya bisa melihat nilai kadar Karbon Monoksida di web. Berikut adalah gambar rangkaian Sensor MQ-7.

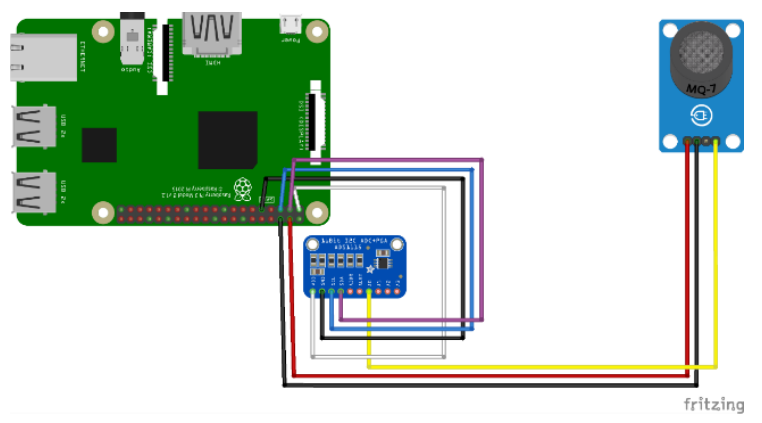

Gambar 3 Rangkaian Aensor MQ-7 (karbon monoksida).

Sensor dust sharp gp2y1010au0f (debu) merupakan rangkaian yang terhubung dengan raspberry untuk membaca nilai parameter Debu yang terdapat pada jalan raya maupun pabrik. Raspberry pi tidak mempunyai pin analog maka digunakan ADC (Analog to digital converter). Kemudian sensor ini 
RESISTOR (Elektronika Kendali Telekomunikasi Tenaga Listrik Komputer) Vol. 4 No. 1 e-ISSN : 2621-9700, p-ISSN : 2654-2684

membaca parameter yang kemudian dikirim ke web untuk ditampilkan pada dashboard web tersebut. System web ini mempunyai status pada parameter Debu yang mempunyai standar. GP2Y1010AU0F adalah sensor debu dengan penginderaan optik sistem. Dioda pemancar inframerah (IRED) dan fototransistor diatur secara diagonal ke dalam perangkat ini. Ini mendeteksi cahaya yang dipantulkan dari debu di udara. Terutama, ini efektif untuk mendeteksi partikel yang sangat halus seperti asap rokok. Selain itu dapat membedakan asap dari debu rumah dengan pola pulsa tegangan keluaran [8] .System tersebut dapat di monitoring via handphone dan laptop supaya bisa melihat nilai kadar Debu di web. Berikut adalah gambar rangkaian Sensor dust sharp gp2y1010au0f.

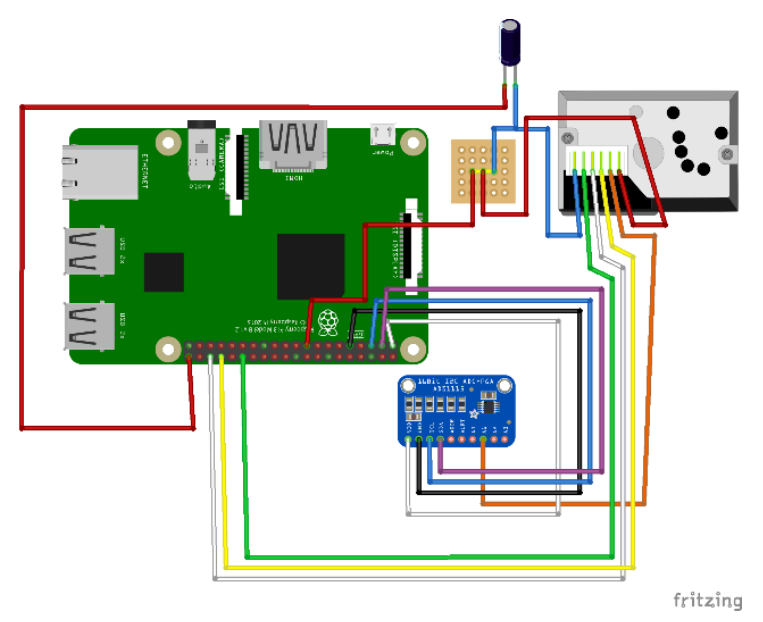

Gambar 4 Rangkaian Sensor dust sharp gp2y1010au0f.

Rangkaian keseluruhan mempunyai 2 sensor yaitu : Sensor MQ-7 (Karbon Monoksida) dan sensor dust sharp gp2y1010auOf. rangkaian yang terhubung dengan raspberry untuk membaca nilai parameter karbon monoksida dan sensor yang terdapat pada jalan raya maupun pabrik. Sensor - sensor ini mengkonversikan pin analog maka digunakan ADC (Analog to digital converter) untuk terhubung dengan raspberry pi. Kemudian sensor ini membaca parameter yang kemudian dikirim ke web untuk ditampilkan pada dashboard web tersebut. System web ini mempunyai status pada parameter Karbon Monoksida dan Sensor Debu. System tersebut dapat di monitoring via handphone dan laptop supaya bisa melihat nilai kadar Karbon Monoksida dan sensor Debu di web. Berikut adalah gambar rangkaian Sensor MQ-7.

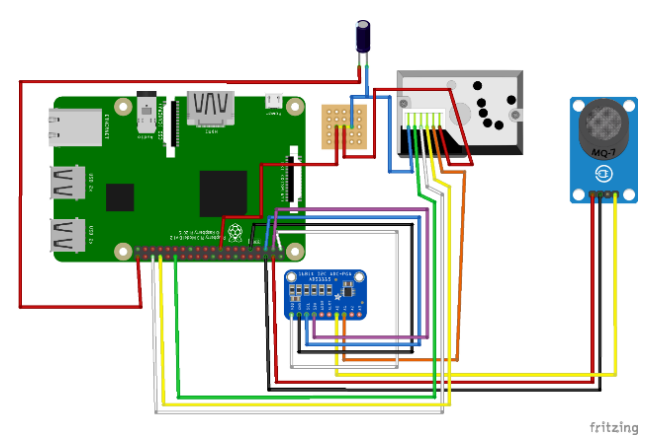

Gambar 5 Rangkaian sensor keseluruhan.

Fungsi flowchart perangkat lunak sebagai komunikasi antara raspberry, dan sensor - sensor tersebut. System ini berfungsi apabila raspberry pi terhubung dengan handphone dan laptop pada hostpot raspberry agar bisa masuk interface website monitoring pada kualitas udara karbon monoksida, dan debu. System ini menggunakan sensor MQ-7 (Karbon Monoksida), dan Sensor Debu. Kemudian parameter dari sensor - sensor tersebut akan dikirim dan ditampilkan melalui website. Kemudian system ini monitoring. Berikut adalah flowchart perangkat lunak dibawah ini.

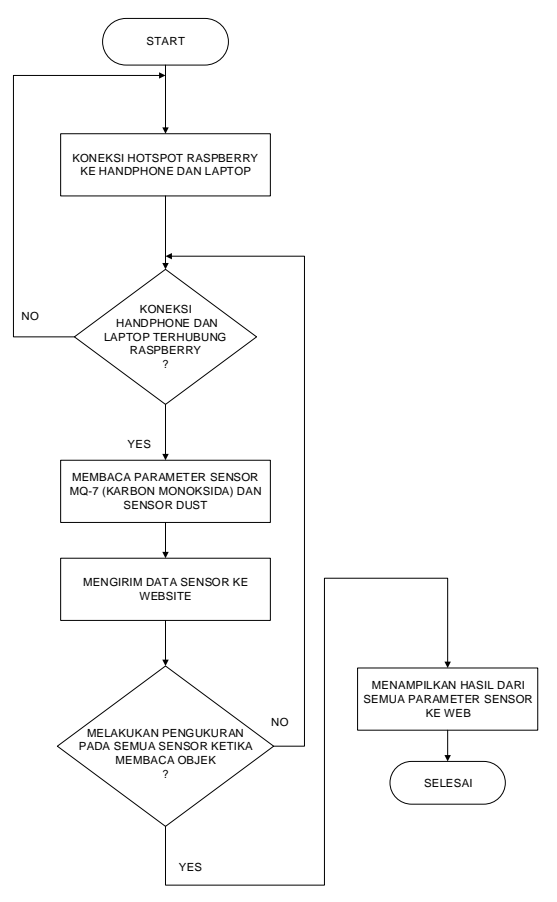

Gambar 6 Flowchart perangkat lunak.

\section{PENGUJIAN DAN ANALISA}

Pengujian Perangkat Lunak dan Perangkat Keras

Pengujian perangkat lunak dilakukan dengan membuka halaman website dengan http://192.168.1.1/index.php yang telah dibuat. apabila ingin memasuki interface website maka 
RESISTOR (Elektronika Kendali Telekomunikasi Tenaga Listrik Komputer) Vol. 4 No. 1 e-ISSN : 2621-9700, p-ISSN : 2654-2684

handphone ataupun laptop harus terhubung dengan hostpot raspberry pi supaya di monitoring melalui handphone maupun laptop. Pada pengujian ini hanya monitoring pada halaman website pada layer untuk mengaktifkan sensor Karbon Monoksida, dan sensor dust (Debu).

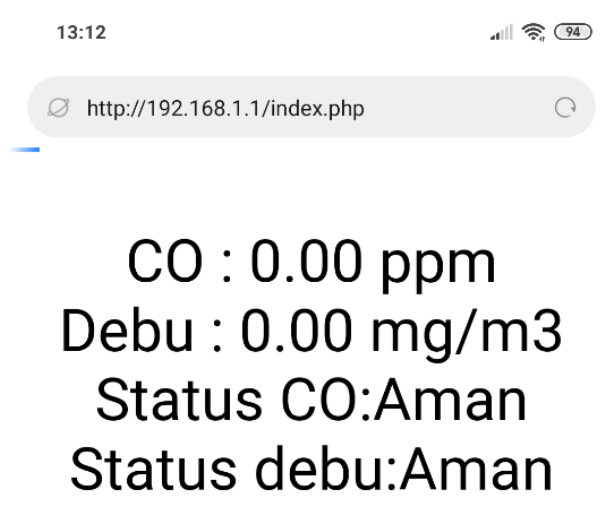

Gambar 7 Monitoring sensor penggunaan kualitas udara (karbon monoksida) dan debu.

Pada pengujian perangkat lunak monitoring sensor hanya menunjukan hasil dari semua sensor yang bekerja dan menampilkan dalam sebuah data yang mudah dibaca oleh user dari sensor MQ-7 (karbon monoksida), sensor Dust.

Pengujian sensor MQ-7 (Karbon Monoksida) ini bertujuan untuk mengetahui kadar Karbon Monoksida dengan Batas Aman dan Batas Bahaya pada udara yang menjadi sampel percobaan. Prinsip Kerja sensor Karbon Monoksida berfungsi mengukur Kadar Karbon Monoksida dalam satuan ppm. Pengujian ini memiliki 3 pengukuran yaitu dengan waktu pagi aktivitas perkantoran, aktivitas makan siang, dan aktivitas pulang perkantoran, dan melakukan terhadap alat ukut karbon monoksida meter. Pengujian sensor MQ-7 di bagi menjadi 2 pengujian yaitu :

- Pengujian MQ-7 di PT. HIBA PRIMA SEJAHTERA.

- Pengujian MQ-7 di sekitar jalan yos sudarso.

- Pengujian MQ-7 di sekitar rawamangun.

Pengujian ini bertujuan mengukur kadar karbon monoksida yang terdapat di PT. HIBA PRIMA SEJAHTERA dengan mengukur setiap 2 jam sekali untuk mendapatkan kondisi kadar pada perusahaan tersebut. Perangkat ADS1113, ADS1114, dan ADS1115 (ADS111x) presisi, daya rendah, 16bit, kompatibel dengan I2C, konverter analog-kedigital [9].

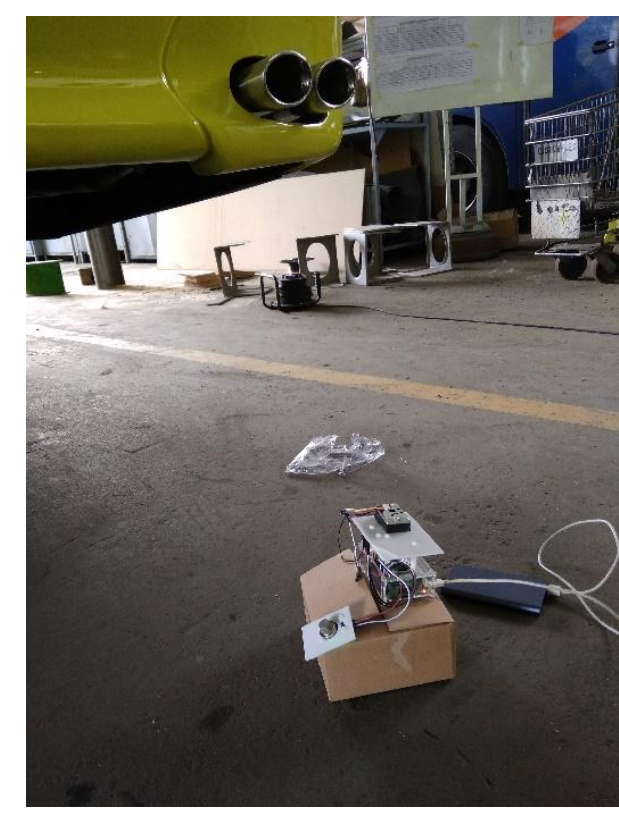

Gambar 8 Pengujian Sensor MQ-7 di PT. HIBA PRIMA SEJAHTERA.

Pengujian ini bertujuan mengukur perbandingan antara kadar karbon monoksida web dengan karbon monoksida menggunakan alat ukur co mter. Berikut table perbandingan karbon monoksida web dengan karbon monoksida meter.

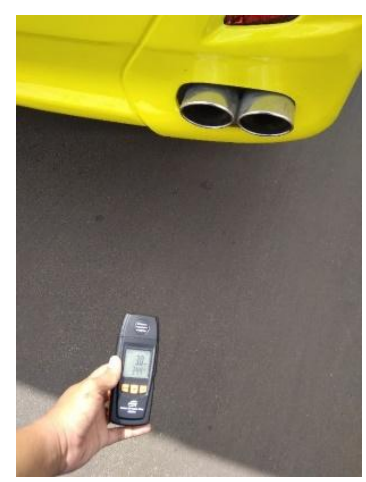

Gambar 9 Pengujian karbon monoksida menggunakan CO meter di PT. HIBA PRIMA SEJAHTERA dengan Rpm Stasioner (0 Rpm)

Tabel 1 Perbandingan pengujian karbon monoksida (web) dengan CO meter di PT. HIBA PRIMA SEJAHTERA pada jarak 2 meter, dan rpm Stasioner (0 Rpm). 
RESISTOR (Elektronika Kendali Telekomunikasi Tenaga Listrik Komputer) Vol. 4 No. 1 e-ISSN : 2621-9700, p-ISSN : 2654-2684

\begin{tabular}{|l|l|l|l|l|l|}
\hline No. & Waktu & $\begin{array}{l}\text { Ppm } \\
\text { (web) }\end{array}$ & $\begin{array}{l}\text { Ppm } \\
(\mathbf{c o} \\
\text { meter) }\end{array}$ & $\begin{array}{l}\text { Satuan } \\
\text { Internasional } \\
\left(\mathbf{m g} / \mathbf{m}^{3}\right) \\
\text { website }\end{array}$ & $\begin{array}{l}\text { Satuan } \\
\text { internasional } \\
\mathbf{( m g / \mathbf { m } ^ { 3 } \text { ) CO }} \\
\text { meter }\end{array}$ \\
\hline 1. & 10.00 & 35.50 & 38 & 40.66 & 43.53 \\
\hline 2. & 11.00 & 25.30 & 27 & 29.21 & 30.93 \\
\hline 3. & 13.00 & 28.85 & 31 & 33.05 & 35.51 \\
\hline 4. & 14.00 & 26.65 & 28 & 30.53 & 32.07 \\
\hline 5. & 15.00 & 25.40 & 28 & 29.09 & 32.07 \\
\hline 6. & 16.00 & 23.80 & 26 & 27.26 & 29.78 \\
\hline
\end{tabular}

Untuk menghitung data ppm ke satuan internasional menggunakan rumus berikut:

$$
\begin{aligned}
& \operatorname{CO}\left(\frac{\mathrm{mg}}{\mathrm{m} 3}\right)=\frac{\text { ppm web } \times \text { masa molar CO }\left(\frac{\mathrm{g}}{\mathrm{mol}}\right)}{24.45} \\
& \operatorname{CO}\left(\frac{\mathrm{mg}}{\mathrm{m} 3}\right)=\frac{35.50 \times 28.01\left(\frac{\mathrm{g}}{\mathrm{mol}}\right)}{24.45} \\
& \operatorname{CO}\left(\frac{\mathrm{mg}}{\mathrm{m} 3}\right)=40.66 \mathrm{mg} / \mathrm{m}^{3}
\end{aligned}
$$

Dari table 4.1. Pengujian ditas menunjukan bahwa terjadi perbedaan yang tidak jauh antara ppm menggunakan website dengan ppm dengan co meter menunjukan presentasi kesalahan antara ppm yang di website. Pengujian nilai $\mathrm{CO}$ website dapat dihitung dengan satuan internasional yaitu $\mathrm{mg} / \mathrm{m}^{3}$ dengan nilai terendah pada pengukuran $\mathrm{CO}$ web $27.26 \mathrm{mg} / \mathrm{m}^{3}$ pukul 16.00, dan nilai tertinggi pada pengukuran $\mathrm{CO}$ web sebesar $40.66 \mathrm{mg} / \mathrm{m}^{3}$ yaitu pukul 10.00 . sedangkan Pengujian nilai CO meter dapat dihitung dengan satuan internasional yaitu $\mathrm{mg} / \mathrm{m}^{3}$ dengan nilai terendah $29.78 \mathrm{mg} / \mathrm{m}^{3}$ pada pukul 16.00 , dan nilai tertinggi pada pengukuran dengan $\mathrm{CO}$ meter sebesar $43.53 \mathrm{mg} / \mathrm{m}^{3}$ pada pukul 10.00. dikarenakan pengukuran tersebut masih standar batas aman kadar kualitas udara yaitu sebesar $50 \mathrm{mg} / \mathrm{m}^{3}$.

Pengujian ini bertujuan mengukur karbon monoksida di daerah jalan yos sudarso dengan pengambilan 3 waktu yaitu waktu berangkat kerja (pagi), waktu istirahat(siang), dan waktu pulang kerja (sore). Pengujian ini membandingkan antara ppm website dengan ppm CO meter. Supaya mendapatkan hasil presentasi kesalahan antara ppm website dengan ppm CO meter. Berikut table perbandingan pengujian ppm website dengan ppm $\mathrm{CO}$ meter.

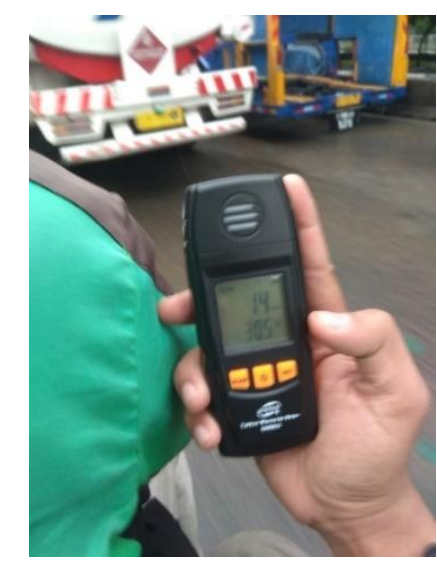

Gambar 10 a. Perbandingan pengujian karbon monoksida (MQ-7) website, dan CO meter di daerah sekitar jalan yos sudarso Jakarta.

Tabel 2 Perbandingan pengujian ppm website dengan ppm CO meter di daerah sekitaran yos sudarso.

\begin{tabular}{|l|l|l|l|l|l|}
\hline No. & Waktu & $\begin{array}{l}\text { Ppm } \\
\text { (web) }\end{array}$ & $\begin{array}{l}\text { Ppm } \\
(\mathbf{c o} \\
\text { meter) }\end{array}$ & $\begin{array}{l}\text { Satuan } \\
\text { Internasional } \\
\left(\mathbf{m g}_{\mathbf{m}} \mathbf{3}\right) \\
\text { website }\end{array}$ & $\begin{array}{l}\text { Satuan } \\
\text { internasional } \\
\left(\mathbf{m g} / \mathbf{m}^{\mathbf{3}} \mathbf{)} \mathbf{C O}\right. \\
\text { meter }\end{array}$ \\
\hline 1. & 07.00 & 12.50 & 14.00 & 14.32 & 16.03 \\
\hline 2. & 12.00 & 3.80 & 5.00 & 4.35 & 5.72 \\
\hline 3. & 17.00 & 15.20 & 17.00 & 17.41 & 19.47 \\
\hline
\end{tabular}

Untuk menghitung data ppm ke satuan internasional menggunakan rumus berikut:

$$
\begin{aligned}
& \operatorname{Co}\left(\frac{\mathrm{mg}}{\mathrm{m} 3}\right)=\frac{\text { ppm web } \times \text { masa molar CO }\left(\frac{\mathrm{g}}{\mathrm{mol}}\right)}{24.45} \\
& \operatorname{CO}\left(\frac{\mathrm{mg}}{\mathrm{m} 3}\right)=\frac{12.50 \times 28.01\left(\frac{\mathrm{g}}{\mathrm{mol}}\right)}{24.45} \\
& \operatorname{Co}\left(\frac{\mathrm{mg}}{\mathrm{m} 3}\right)=14.32 \mathrm{mg} / \mathrm{m}^{3}
\end{aligned}
$$

Dari table 2 pengujian ditas menunjukan bahwa terjadi perbedaan yang tidak jauh antara ppm menggunakan website dengan ppm dengan co meter menunjukan presentasi kesalahan antara ppm yang di website. Pengujian nilai $\mathrm{CO}$ website dapat dihitung dengan satuan internasional yaitu $\mathrm{mg} / \mathrm{m}^{3}$ dengan nilai terendah pada pengukuran $\mathrm{CO}$ web $4.35 \mathrm{mg} / \mathrm{m}^{3}$ pukul 12.00, dan nilai tertinggi pada pengukuran $\mathrm{CO}$ web sebesar $17.41 \mathrm{mg} / \mathrm{m}^{3}$ yaitu pukul 17.00 . sedangkan Pengujian nilai $\mathrm{CO}$ meter dapat dihitung dengan satuan internasional yaitu $\mathrm{mg} / \mathrm{m}^{3}$ dengan nilai terendah $5.72 \mathrm{mg} / \mathrm{m}^{3}$ pada pukul 12.00 , dan nilai tertinggi pada pengukuran dengan $\mathrm{CO}$ meter sebesar $19.47 \mathrm{mg} / \mathrm{m}^{3}$ pada pukul 17.00. dikarenakan pengukuran tersebut masih standar batas aman kadar kualitas udara yaitu sebesar $50 \mathrm{mg} / \mathrm{m}^{3}$. 
RESISTOR (Elektronika Kendali Telekomunikasi Tenaga Listrik Komputer) Vol. 4 No. 1 e-ISSN : 2621-9700, p-ISSN : 2654-2684

Pengujian ini bertujuan mengukur karbon monoksida di daerah sekitar rawamangun dengan pengambilan 3 waktu yaitu waktu berangkat kerja (pagi), waktu istirahat (siang), dan waktu pulang kerja (sore). Pengujian ini membandingkan antara ppm website dengan ppm CO meter. Supaya mendapatkan hasil presentasi kesalahan antara ppm website dengan ppm CO meter. Berikut table perbandingan pengujian ppm website dengan ppm CO meter.

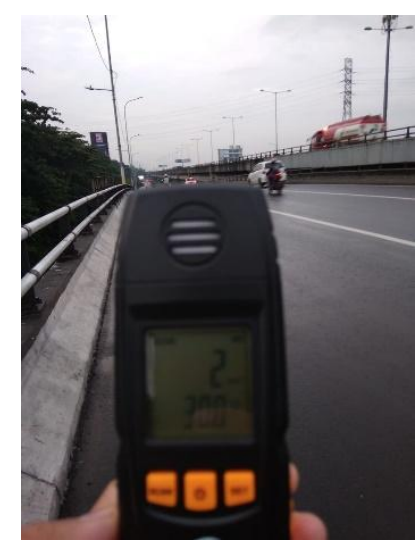

Gambar 11 Perbandingan pengujian karbon monoksida (MQ-7) website dan CO meter di daerah sekitar Rawamangun Jakarta Timur.

Tabel 3 Perbandingan pengujian ppm website dengan ppm CO meter di daerah sekitaran Rawamangun

\begin{tabular}{|c|c|c|c|c|c|}
\hline No. & Waktu & $\begin{array}{c}\text { Ppm } \\
\text { (web) }\end{array}$ & $\begin{array}{c}\text { Ppm } \\
(\mathbf{c o} \text { meter) }\end{array}$ & $\begin{array}{c}\text { Satuan } \\
\text { Internasional } \\
\left(\mathbf{m g} / \mathbf{m}^{3}\right) \\
\text { website }\end{array}$ & $\begin{array}{c}\text { Satuan } \\
\text { internasional } \\
\left(\mathbf{m g} / \mathbf{m}^{\mathbf{3}} \mathbf{)} \mathbf{C O}\right. \\
\mathbf{m e t e r}\end{array}$ \\
\hline 1. & 07.00 & 1.75 & 2.00 & 2.004 & 2.29 \\
\hline 2. & 12.00 & 2.70 & 4.00 & 3.09 & 3.53 \\
\hline 3. & 17.00 & 13.80 & 15.00 & 15.80 & 18.10 \\
\hline
\end{tabular}

Untuk menghitung data ppm ke satuan internasional menggunakan rumus berikut:

$$
\begin{aligned}
& \operatorname{CO}\left(\frac{\mathrm{mg}}{\mathrm{m} 3}\right)=\frac{\text { ppm web } \times \text { masa molar CO }\left(\frac{\mathrm{g}}{\mathrm{mol}}\right)}{24.45} \\
& \operatorname{CO}\left(\frac{\mathrm{mg}}{\mathrm{m} 3}\right)=\frac{1.75 \times 28.01\left(\frac{\mathrm{g}}{\mathrm{mol}}\right)}{24.45} \\
& \operatorname{CO}\left(\frac{\mathrm{mg}}{\mathrm{m} 3}\right)=14.32 \mathrm{mg} / \mathrm{m}^{3}
\end{aligned}
$$

Dari table 3 pengujian ditas menunjukan bahwa terjadi perbedaan yang tidak jauh antara ppm menggunakan website dengan ppm dengan co meter menunjukan presentasi kesalahan antara ppm yang di website. Pengujian nilai $\mathrm{CO}$ website dapat dihitung dengan satuan internasional yaitu $\mathrm{mg} / \mathrm{m}^{3}$ dengan nilai terendah pada pengukuran $\mathrm{CO}$ web $2.004 \mathrm{mg} / \mathrm{m}^{3}$ pukul 07.00, dan nilai tertinggi pada pengukuran $\mathrm{CO}$ web sebesar $15.80 \mathrm{mg} / \mathrm{m}^{3}$ yaitu pukul 17.00.

sedangkan pengujian nilai $\mathrm{CO}$ meter dapat dihitung dengan satuan internasional yaitu $\mathrm{mg} / \mathrm{m}^{3}$ dengan nilai terendah $2.29 \mathrm{mg} / \mathrm{m}^{3}$ pada pukul 07.00 , dan nilai tertinggi pada pengukuran dengan $\mathrm{CO}$ meter sebesar $18.10 \mathrm{mg} / \mathrm{m}^{3}$ pada pukul 17.00. dikarenakan pengukuran tersebut masih standar batas aman kadar kualitas udara yaitu sebesar $50 \mathrm{mg} / \mathrm{m}^{3}$.

Pengujian sensor dust sharp gp2y1010au0f ini bertujuan untuk mengetahui kadar debu dengan Batas Aman dan Batas Bahaya pada udara yang menjadi sampel percobaan. Prinsip Kerja sensor debu berfungsi mengukur Kadar debu dalam satuan $\mathrm{mg} / \mathrm{m} 3$. Pengujian ini memiliki 3 pengukuran yaitu dengan waktu pagi aktivitas perkantoran, aktivitas makan siang, dan aktivitas pulang perkantoran. Pengujian dust di bagi menjadi beberapa pengujian yaitu pengujian sensor debu di sekitaran yos sudarso dan pengujian sensor debu di sekitaran rawamangun.

Pengujian ini bertujuan untuk mengukur suatu kadar debu yang terdapat di sekitar yos sudarso. Kemudian kondisi debu yang terdapat daerah tersebut di ukur dengan kadar debu dengan pengukuran website. Pengukuran ini tidak dapat diperbandingkan dikarenakan kekurangan alat pendukung untuk dust meter. Pengujian ini dilakukan 3 pengujian yaitu pada waktu. Berikut adalah table untuk pengujian debu di sekitar yos sudarso.

Tabel 4 Pengujian kadar debu sharp gp2y1010au0f di sekitar yos sudarso.

\begin{tabular}{|l|l|l|}
\hline No. & Waktu & $\begin{array}{l}\text { Debu } \mathbf{~ m g / m 3} \\
\text { (website) }\end{array}$ \\
\hline 1. & 09.00 & 0,0259 \\
\hline 2. & 13.00 & 0,0892 \\
\hline 3. & 17.00 & 0,0354 \\
\hline
\end{tabular}

Dari table pengujian table 4.4. diatas menunjukkan bahwa kadar debu pukul 09.00 sebesar 0,0259 mg/m3, kadar debu pada pukul 13.00 sebesar 0,0892 $\mathrm{mg} / \mathrm{m} 3$, dan kadar debu pada pukul 17.00 sebesar $0,00354 \mathrm{mg} / \mathrm{m} 3$.

Pengujian ini bertujuan untuk mengukur suatu kadar debu yang terdapat di sekitar rawamangun. Kemudian kondisi debu yang terdapat daerah tersebut di ukur dengan kadar debu dengan pengukuran website. Pengukuran ini tidak dapat diperbandingkan dikarenakan kekurangan alat pendukung untuk dust meter. Pengujian ini dilakukan 3 pengujian yaitu pada waktu. Berikut adalah table untuk pengujian debu di sekitar rawamangun.

Tabel 5 Pengujian kadar debu sharp gp2y1010au0f di sekitar rawamangun 
RESISTOR (Elektronika Kendali Telekomunikasi Tenaga Listrik Komputer) Vol. 4 No. 1 e-ISSN : 2621-9700, p-ISSN : 2654-2684

\begin{tabular}{|l|l|l|}
\hline No. & Waktu & $\begin{array}{l}\text { Debu mg/m3 } \\
\text { (website) }\end{array}$ \\
\hline 1. & 09.00 & 0,0209 \\
\hline 2. & 13.00 & 0,0657 \\
\hline 3. & 17.00 & 0,0349 \\
\hline
\end{tabular}

[6] E. Rakhman, F. Candrasyah, and F. D. Sutera, "Raspberry Pi: Mikrokontroler Mungil Yang Serba Bisa," Yogyak. Penerbit Andi, 2014.

[7] “www.rs-components.com/raspberrypi." .

[8] "GP2Y1010AU0F Compact Optical Dust Sensor.".

menunjukkan bahwa kadar debu pukul 09.00 sebesar $0,0209 \mathrm{mg} / \mathrm{m} 3$, kadar debu pada pukul 13.00 dalam kondisi status sedang yaitu sebesar $0,0657 \mathrm{mg} / \mathrm{m}^{3}$, dan kadar debu pada pukul 17.00 sebesar 0,0349 $\mathrm{mg} / \mathrm{m}^{3}$.

\section{KESIMPULAN}

Dari pengujian dan Analisa dapat disimpulkan bahwa pengujian yang dilakukan pada pagi hari dengan kondisi macet pengukuran $\mathrm{CO}$ meter masih minimal dikarenakan suhu udara dipagi hari masih belum tercemar. Pada alat monitoring kualitas udara karbon monoksida, dan debu hanya dapat diukur ketika diluar ruangan seperti jalan raya yang mempunyai rasio kemacaten, dan masih belum bisa diuji coba didalam ruangan. Pada pengujian monitoring kualitas udara karbon monoksida, dan debu harus diselaraskan mengenai standarisasi satuan internasional yang terdapat pada sensor karbon monoksida (MQ-7), dan sensor debu sharp gp2y1010au0f.

\section{DAFTAR PUSTAKA}

[1] O. A. Popoola et al., "Use of networks of low cost air quality sensors to quantify air quality in urban settings," Atmos. Environ., vol. 194, pp. 58-70, 2018.

[2] N. S. Ngo, S. V. J. Asseko, M. O. Ebanega, S. M. A. Allo'o, and P. Hystad, "The relationship among PM2. 5, traffic emissions, and socioeconomic status: Evidence from Gabon using low-cost, portable air quality monitors," Transp. Res. Part Transp. Environ., vol. 68, pp. 2-9, 2019.

[3] R. Purbakawaca et al., "Rancang Bangun Alat Ukur Pm10 Rendah Biaya Menggunakan Sensor Debu Gp2y1010au0f," J. ONLINE Phys., vol. 3, no. 1, pp. 6-13, 2017.

[4] K. Azhari and L. A. Fatah, "PERANCANGAN SISTEM MONITORING KUALITAS UDARA DALAM RUANGAN DENGAN KOMUNIKASI TCP/IP BERBASIS MIKROKONTROLER ATMEGA16."

[5] P. Membrey and D. Hows, Learn Raspberry Pi with Linux. Springer, 2013. 
RESISTOR (Elektronika Kendali Telekomunikasi Tenaga Listrik Komputer) Vol. 4 No. 1 e-ISSN : 2621-9700, p-ISSN : 2654-2684 